IBIMA Publishing

International Journal of Gastroenterology Research and Practice

http://www.ibimapublishing.com/journals/GAST/gast.html

Vol. 2014 (2014), Article ID 343907, 10 pages

DOI: $10.5171 / 2014.343907$

Research Article

\title{
Analgesia in Patients with Acute Pancreatitis: A Cry for Help
}

\author{
Meegodage Ruwan S. Perera ${ }^{1}$, Megan Z. Tattersall ${ }^{2}$ and Arkadiusz Peter Wysocki ${ }^{3}$ \\ ${ }^{1,2,3}$ Logan Hospital Queensland, Australia \\ ${ }^{3}$ Griffith University School of Medicine University Drive \\ Meadowbrook Queensland, Australia
}

Correspondence should be addressed to: A. Peter Wysocki; arek_p@ecn.net.au

Received date: 9 January 2014; Accepted date: 8 February 2014; Published date: 14 May 2014

Academic Editor: Karin N. Westlund

Copyright (C) 2014. Meegodage Ruwan S. Perera, Megan Z. Tattersall and Arkadiusz Peter Wysocki.

Distributed under Creative Commons CC-BY 3.0

\begin{abstract}
Introduction: Acute Pancreatitis has been referred to as the most terrible of abdominal conditions, yet guidelines on the provision of analgesia are limited. We hypothesized this lack of clear guidelines results in a clinician specific approach to the administration of analgesia. This study was carried out to test this hypothesis, document the analgesia received by patients with acute pancreatitis, and compare those with alcohol and biliary etiology. Materials and Methods: Retrospective review of medical records of adult patients with acute pancreatitis admitted over a 7 year period to a 250 bed outer metropolitan hospital. All analgesics received on the day of admission and cumulative dose over the first three days were recorded. Results: Analgesia was predominantly opiate based. 55\% of patients who received opioids, had at least half the cumulative three day dose on the first day of hospitalization. Acetaminophen and Non-Steroidal Anti-Inflammatory drugs are underutilized ( $26 \%$ and $81 \%$ did not receive any, respectively), but hyoscine may be over prescribed. Conclusions: As expected, opiate analgesics are administered to most patients with acute pancreatitis, but non-opiate analgesics are underutilized.
\end{abstract}

Keywords: Pancreatitis; Analgesia; Analgesics, Opioid; Gallstones; Alcohol-Related Disorders

\section{Introduction}

Gallstones and alcohol are the two most commonly identified causes of Acute Pancreatitis (AP) (Wysocki and Carter, 2007). At least $95 \%$ of patients will present with acute moderate to severe upper abdominal pain, often radiating to the back (50\%) with vomiting (70\%) (Koizumi et al., 2006). Pain is often eased by sitting forward and reaches its peak within an hour (Jakobs et al., 2000). The majority of

Cite this Article as: Meegodage Ruwan S. Perera, Megan Z. Tattersall and Arkadiusz Peter Wysocki (2014)," Analgesia in Patients with Acute Pancreatitis: A Cry for Help ", International Journal of Gastroenterology Research and Practice, Vol. 2014 (2014), Article ID 343907, 
patients will have a self-limiting course while the leading independent predictor of mortality is organ failure, persisting longer than 48 hours during the first week of illness (Buter et al., 2002).

Traditional teaching has been that pethidine (meperidine) be prescribed in preference to morphine as the latter causes sphincter of Oddi (SO) spasm while the former does not. Two recent reviews of these drugs have not resolved the controversy (Isenhower and Mueller, 1998, Thompson, 2001). Given the limited focus on analgesia in Acute Pancreatitis guidelines, we wondered whether the multitude of available analgesics and the ongoing morphine vs. pethidine debate have resulted in a clinician specific approach to prescribing analgesia in patients with AP. We also wished to compare the analgesia requirements in patients with alcohol-related and gallstone induced acute pancreatitis, and to determine if there is any correlation between lipase concentration on admission and opiate requirement. A comparison of analgesics in those with mild AP and the more severe forms was also undertaken.

\section{Materials and Methods}

Data were extracted through Transition II database (Queensland Health administrative database). Potential patients with acute pancreatitis (AP) were identified based on International Statistical Classification of Diseases and Related Health Problems, Tenth Revision, Australian Modification (ICD-10-AM) codes. Each entry was manually verified by chart review to ensure only those with AP were included. The diagnosis of AP was made on clinical grounds supported by a lipase more than three times the upper limit of normal or imaging evidence. The study period was from January 2002 to April 2008. Etiology was categorized into alcohol-related, gallstone or other. Analgesics (and doses) administered on the day of admission (day one) and cumulatively over the first three days were recorded.
Pain level as described by the patient on arrival to Emergency Department was recorded. Where a $0-10$ numeric rating scale was used by the clinician, mild was defined as a score of 1 to 3 ; moderate as 4 to 6 ; and severe as $\geq 7$.

Due to the wide variety of opiate analgesics prescribed (morphine, meperidine (pethidine), fentanyl, tramadol, codeine, oxycodone), we determined opiate use as morphine-equivalent (ME). ME represents an approximation as the efficacy and safety profiles differ for each pharmaceutical agent. According to established conversion ratios (Royal Australasian College of General Practicioners, 2012), numerically ME in milligrams was calculated as: $100 \%$ morphine dose $(\mathrm{mg})+10 \%$ pethidine dose $(\mathrm{mg})+80 \%$ fentanyl dose (micrograms) + $7.5 \%$ tramadol dose $(\mathrm{mg})+16 \%$ codeine dose $(\mathrm{mg})+70 \%$ oxycodone dose $(\mathrm{mg})$. Due to low numbers, moderately severe and severe AP are reported as one group. Assessment of adverse effects from analgesics was not performed as it is beyond the scope of this paper.

Ethical approval was obtained from the Metro South Health Service District as well as from the local hospital authority. Patient consent was not required as this study represents a retrospective analysis of a database.

Analgesic use has been analyzed per admission. Non-parametric regression analysis was performed using Microsoft Excel (Redmond, Washington: Microsoft, 2007). The Z-test for the difference between two proportions was performed for nominal variables. Significance values were based on two-tailed tests, with $\mathrm{p}<$ 0.05 considered statistically significant.

\section{Results}

20 of the 561 presentations to the Emergency Department with AP resulted in transfer to a private hospital for ongoing care and are excluded from the analysis. 424 patients were admitted 541 times: 169 admissions with alcohol-related AP (98 patients), 215 admissions with gallstone pancreatitis (192 patients), and 157 
admissions with other causes (134 patients). 477 admissions were for mild pancreatitis and 64 for moderately severe and severe pancreatitis (Banks et al., 2013). Of the 64 with non-mild AP, ten had local complications where as 54 had organ failure without local complications, such as acute necrotic collection or acute fluid collection. 42 admissions were for patients with a lipase concentration below three times the upper limit of normal (7.8\%), and almost all of them had imaging evidence of pancreatitis. 6 patients died ( 2 gallstone, 2 alcohol-related and 2 other etiology). Demographic data are shown in Table 1.

Table 1: Demographic data

\begin{tabular}{|c|c|c|c|c|c|}
\hline & $\begin{array}{l}\text { Alcohol } \\
N=169 \\
(31.2 \%)\end{array}$ & $\begin{array}{l}\text { Gallstone } \\
N=215 \\
(39.7 \%)\end{array}$ & $\begin{array}{l}\text { Other } \\
N=157 \\
(29.0 \%)\end{array}$ & $\begin{array}{l}\text { Total } \\
\mathbf{N}=\mathbf{5 4 1}\end{array}$ & $\begin{array}{l}\text { P value } \\
\text { Alcohol } \\
\text { vs } \\
\text { Gallstone }\end{array}$ \\
\hline $\begin{array}{l}\text { Median age on } \\
\text { admission, years }\end{array}$ & 40 & 49 & 50 & 46 & $<0.001$ \\
\hline $\begin{array}{l}\text { Median Lipase } \\
\text { concentration on } \\
\text { admission (U/L) }\end{array}$ & 627 & 2620 & 960 & 1390 & $<0.001$ \\
\hline $\begin{array}{l}\text { Median Length of } \\
\text { Hospital Stay in days } \\
\text { (range) }\end{array}$ & $4(1-50)$ & $\begin{array}{l}6(1- \\
171)\end{array}$ & $4(1-21)$ & $4(1-171)$ & 0.003 \\
\hline $\begin{array}{l}\text { Severity (mild / } \\
\text { moderately severe / } \\
\text { severe) }\end{array}$ & $159 / 7 / 3$ & $\begin{array}{l}178 / 16 / \\
21\end{array}$ & $\begin{array}{l}140 / 6 / \\
11\end{array}$ & 477 / 29 / 35 & 0.001 \\
\hline
\end{tabular}

505 presentations were with abdominal pain (93.3\%). 21 presentations were with chest pain $(3.9 \%), 13$ with feeling generally unwell $(2.4 \%)$ and two with back pain only $(0.4 \%)$. The level of abdominal pain on presentation was recorded on 238 occasions (44.0\% of cohort): 24 mild (10.1\%), 21 moderate (8.8\%) and 193 severe $(81.1 \%)$. Severe vs. non-severe pain was not related to frequency of analgesia administration and dose of analgesia on day 1 as well as over the first three days of admission (data not shown). Severe pain on presentation was not related to the lipase concentration; etiology of acute pancreatitis; and whether or not the patient ultimately ended up with severe acute pancreatitis (data not shown).

Table 2 shows that on day 1, opioids were not administered during $16.8 \%$ admissions. Those ultimately diagnosed with gallstone AP were more likely not to receive any opioids than patients with alcohol-related AP (19.1\% vs. $8.3 \%$ respectively $p=0.003)$. Furthermore, patients with alcohol-related AP received a higher dose of morphine equivalent opiate analgesia on the day of admission compared to those with gallstone pancreatitis $(17.5 \mathrm{mg}$ vs. $12.5 \mathrm{mg}$ respectively; $\mathrm{p}<0.001)$. Acetaminophen (paracetamol) and hyoscine were administered during less than $50 \%$ of admissions. 
Table 2: Analgesia on day one of admission

\begin{tabular}{|c|c|c|c|c|c|c|}
\hline & & $\begin{array}{l}\text { Alcohol } \\
\text { N = } 169\end{array}$ & $\begin{array}{l}\text { Gallstone } \\
N=215\end{array}$ & $\begin{array}{l}\text { Other } \\
N=157\end{array}$ & $\begin{array}{l}\text { Total } \\
\mathbf{N}=\mathbf{5 4 1}\end{array}$ & $\begin{array}{l}\text { P value } \\
\text { Alcohol } \\
\text { vs. } \\
\text { Gallstone } \\
\end{array}$ \\
\hline \multirow[t]{2}{*}{$\begin{array}{l}\text { Morphine } \\
\text { Equivalent }\end{array}$} & $\begin{array}{l}\text { Number } \\
\text { received } \\
(\%)\end{array}$ & $\begin{array}{l}155 \\
(91.7 \%)\end{array}$ & $\begin{array}{l}174 \\
(80.9 \%)\end{array}$ & $\begin{array}{l}121 \\
(77.1 \%)\end{array}$ & $\begin{array}{l}450 \\
(83.2 \%)\end{array}$ & 0.003 \\
\hline & \begin{tabular}{|l} 
Median \\
dose \\
received, \\
mg \\
\end{tabular} & 17.5 & 12.5 & 15 & 15 & $<0.001$ \\
\hline \multirow[t]{2}{*}{ Acetaminophen } & \begin{tabular}{|l|}
$\begin{array}{l}\text { Number } \\
\text { received } \\
(\%)\end{array}$ \\
\end{tabular} & $\begin{array}{l}73 \\
(43.2 \%)\end{array}$ & $\begin{array}{l}94 \\
(43.7 \%)\end{array}$ & $\begin{array}{l}64 \\
(40.8 \%)\end{array}$ & $\begin{array}{l}231 \\
(42.7 \%)\end{array}$ & 0.918 \\
\hline & \begin{tabular}{|l} 
Median \\
dose \\
received, \\
$\mathrm{g}$ \\
\end{tabular} & 1 & 1 & 1 & 0 & 0.498 \\
\hline \multirow[t]{2}{*}{ Hyoscine } & $\begin{array}{l}\text { Number } \\
\text { received } \\
(\%) \\
\end{array}$ & $\begin{array}{l}43 \\
(25.4 \%)\end{array}$ & $\begin{array}{l}91 \\
(42.3 \%)\end{array}$ & $\begin{array}{l}67 \\
(42.7 \%)\end{array}$ & $\begin{array}{l}201 \\
(37.2 \%)\end{array}$ & 0.001 \\
\hline & $\begin{array}{l}\text { Median } \\
\text { dose } \\
\text { received, } \\
\text { mg }\end{array}$ & 20 & 20 & 20 & 20 & $<0.001$ \\
\hline
\end{tabular}

Table 3 shows that over the first three days of admission, those with alcohol-related AP were more likely to receive opiate analgesia than those with gallstone $\mathrm{AP}$, and the dose received was almost double (42.8mg vs. $22.1 \mathrm{mg}$ respectively; $\mathrm{p}$ < 0.001). Acetaminophen (paracetamol) was administered in more than $70 \%$ of admissions overall but the frequency of use and dose did not differ based on biliary or alcohol etiology. Overall, hyoscine was prescribed during $40.1 \%$ of admissions with a higher rate in those subsequently diagnosed with gallstone pancreatitis compared to alcohol-related disease (46\% vs. $27.8 \%$ respectively, $\mathrm{p}<0.001$ ). NSAIDs were administered during $19.2 \%$ of admissions overall and this rate was not influenced by the etiology of AP ( $p=$ 0.895). 
Table 3: Cumulative analgesia over the first three days of admission

\begin{tabular}{|c|c|c|c|c|c|c|}
\hline & & $\begin{array}{l}\text { Alcohol } \\
N=169\end{array}$ & $\begin{array}{l}\text { Gallstone } \\
N=215\end{array}$ & $\begin{array}{l}\text { Other } \\
N=157\end{array}$ & $\begin{array}{l}\text { Total } \\
N=541\end{array}$ & $\begin{array}{l}\text { P value } \\
\text { Alcohol } \\
\text { vs. } \\
\text { Gallstone }\end{array}$ \\
\hline \multirow[t]{3}{*}{$\begin{array}{l}\text { Morphine } \\
\text { equivalent }\end{array}$} & $\begin{array}{l}\text { Number } \\
\text { received (\%) }\end{array}$ & $\begin{array}{l}160 \\
(94.7 \%)\end{array}$ & $\begin{array}{l}184 \\
(85.6 \%)\end{array}$ & $\begin{array}{l}131 \\
(83.4 \%)\end{array}$ & $\begin{array}{l}475 \\
(87.8 \%)\end{array}$ & 0.004 \\
\hline & $\begin{array}{l}\text { Median dose } \\
\text { received, mg }\end{array}$ & $42.8 \mathrm{mg}$ & $22.1 \mathrm{mg}$ & $27.5 \mathrm{mg}$ & $30.0 \mathrm{mg}$ & $<0.001$ \\
\hline & $\begin{array}{l}\text { Percent who } \\
\text { received }> \\
50 \% \text { of total } \\
\text { dose of opiate } \\
\text { on day of } \\
\text { admission }\end{array}$ & $48.1 \%$ & $58.7 \%$ & $57.3 \%$ & $54.7 \%$ & \\
\hline \multirow[t]{2}{*}{ Acetaminophen } & $\begin{array}{l}\text { Number } \\
\text { received (\%) }\end{array}$ & $\begin{array}{l}132 \\
(78.1 \%) \\
\end{array}$ & $\begin{array}{l}153 \\
(71.1 \%) \\
\end{array}$ & $\begin{array}{l}118 \\
(75.2 \%) \\
\end{array}$ & $\begin{array}{l}403 \\
(74.5 \%) \\
\end{array}$ & 0.123 \\
\hline & $\begin{array}{l}\text { Median dose } \\
\text { received, } \mathrm{g}\end{array}$ & $4 \mathrm{~g}$ & $3 \mathrm{~g}$ & $3 g$ & $3 g$ & 0.068 \\
\hline \multirow[t]{2}{*}{ Hyoscine } & $\begin{array}{l}\text { Number } \\
\text { received (\%) }\end{array}$ & $\begin{array}{l}47 \\
(27.8 \%) \\
\end{array}$ & $\begin{array}{l}99 \\
(46.0 \%) \\
\end{array}$ & $\begin{array}{l}71 \\
(45.2 \%) \\
\end{array}$ & $\begin{array}{l}217 \\
(40.1 \%) \\
\end{array}$ & $<0.001$ \\
\hline & $\begin{array}{l}\text { Median dose } \\
\text { received, mg }\end{array}$ & $20 \mathrm{mg}$ & $20 \mathrm{mg}$ & $20 \mathrm{mg}$ & $20 \mathrm{mg}$ & 0.009 \\
\hline $\begin{array}{l}\text { Non-Steroidal } \\
\text { Anti- } \\
\text { Inflammatory }\end{array}$ & $\begin{array}{l}\text { Number } \\
\text { received (\%) }\end{array}$ & $\begin{array}{l}36 \\
(21.3 \%)\end{array}$ & $\begin{array}{l}47 \\
(21.9 \%)\end{array}$ & $\begin{array}{l}21 \\
(13.4 \%)\end{array}$ & $\begin{array}{l}104 \\
(19.2 \%)\end{array}$ & 0.895 \\
\hline
\end{tabular}

$12.2 \%$ of patients (66) did not receive opioids during the first three days. Patients who received opioids during the first three days were equally likely to receive hyoscine $(\mathrm{p}=0.528)$ and NSAIDs $(\mathrm{p}=$ 0.441 ), as those who received no opioids. The dose of hyoscine in each group was $20.0 \mathrm{mg}(\mathrm{p}=0.175)$. Admissions during which patients received opioids had a $77.1 \%$ rate of acetaminophen (paracetamol) use, while those who did not receive opioids had a $56.1 \%$ rate of acetaminophen (paracetamol) use (p < 0.001). The dose of acetaminophen (paracetamol) in both groups was the same ( $3 g$ vs. $4 \mathrm{~g}$ respectively; $\mathrm{p}=0.912$ ).

Of those who received any opiate (475 patients) over the first three days, $90.1 \%$ (428) received morphine, $13.3 \%$ (63) received meperidine (pethidine), while
$7.8 \%$ received both. There was minor correlation between the lipase concentration on admission and day one $\mathrm{ME}$, as well as opiate dose received during the first three days (data not shown; Pearson correlation coefficient $<0.1$ for both). There was a very strong correlation between day one and total 3 day ME opiate dose (data not shown; Pearson correlation coefficient 0.7 ).

Table 4 shows analgesics received stratified by the severity of AP. There was no statistical difference in the number of mild vs. non-mild AP admissions during which acetaminophen, NSAIDs, Tramadol and opioids were administered. Likewise, the day 1 and up to day three, doses of analgesics received were the same in those with mild and non-mild AP. 
Table 4: Number of admissions during which analgesics were received stratified by severity of pancreatitis

\begin{tabular}{|c|c|c|c|c|}
\hline & & $\begin{array}{l}\text { Mild AP } \\
\mathrm{N}=477\end{array}$ & $\begin{array}{l}\text { Moderately Severe } \\
\text { and Severe AP } \\
\mathrm{N}=\mathbf{6 4}\end{array}$ & $P$ value \\
\hline \multirow[t]{4}{*}{ Acetaminophen } & $\begin{array}{l}\text { Number received } \\
\text { on day } 1\end{array}$ & $210(44.0 \%)$ & $21(32.8 \%)$ & 0.089 \\
\hline & $\begin{array}{l}\text { Median dose day } \\
1(\mathrm{~g})\end{array}$ & $1.0 \mathrm{~g}$ & $1.0 \mathrm{~g}$ & 0.399 \\
\hline & $\begin{array}{l}\text { Number received } \\
\text { over three days }\end{array}$ & 355 (74.4\%) & $48(75.0 \%)$ & 0.921 \\
\hline & $\begin{array}{l}\text { Median dose } \\
\text { over three days } \\
\text { (g) } \\
\end{array}$ & $4.0 \mathrm{~g}$ & $2.5 \mathrm{~g}$ & 0.166 \\
\hline NSAIDs & $\begin{array}{l}\text { Number received } \\
\text { over three days } \\
(\%)\end{array}$ & $91(19.1 \%)$ & $13(20.3 \%)$ & 0.814 \\
\hline \multirow[t]{4}{*}{ Tramadol } & $\begin{array}{l}\text { Number received } \\
\text { on day } 1 \\
(\%) \\
\end{array}$ & $50(10.5 \%)$ & $4(6.3 \%)$ & 0.289 \\
\hline & $\begin{array}{l}\text { Median dose day } \\
1 \text { (g) }\end{array}$ & $100 \mathrm{mg}$ & $100 \mathrm{mg}$ & 0.553 \\
\hline & $\begin{array}{l}\text { Number received } \\
\text { over three days } \\
(\%)\end{array}$ & $103(21.6 \%)$ & $10(15.6 \%)$ & 0.270 \\
\hline & $\begin{array}{l}\text { Median dose } \\
\text { over three days } \\
\text { (g) }\end{array}$ & $250 \mathrm{mg}$ & $200 \mathrm{mg}$ & 0.587 \\
\hline \multirow[t]{4}{*}{$\begin{array}{l}\text { Morphine } \\
\text { Equivalent }\end{array}$} & $\begin{array}{l}\text { Number received } \\
\text { on day } 1(\%)\end{array}$ & 395 (82.8\%) & 55 (85.9\%) & 0.530 \\
\hline & $\begin{array}{l}\text { Median dose on } \\
\text { day } 1(\mathrm{mg})\end{array}$ & $15.0 \mathrm{mg}$ & $16.1 \mathrm{mg}$ & 0.543 \\
\hline & $\begin{array}{l}\text { Number received } \\
\text { over } 3 \text { days }(\%)\end{array}$ & $415(87.0 \%)$ & $60(93.8 \%)$ & 0.121 \\
\hline & $\begin{array}{l}\text { Median dose } \\
\text { over three days } \\
(\mathrm{mg})\end{array}$ & $30.0 \mathrm{mg}$ & $42.0 \mathrm{mg}$ & 0.444 \\
\hline
\end{tabular}

\section{Discussion}

Our study demonstrates that a wide variety of analgesics are prescribed for patients with acute pancreatitis. Opioids constitute the main analgesic - administered during $87.8 \%$ episodes of care. Acetaminophen (paracetamol) is underutilised especially on the day of admission but even by the end of day 3 , one quarter of patients had not received this opiate sparing analgesic. 
NSAID are rarely administered within the first three days ( $<20 \%$ of admissions). Surprisingly, hyoscine was administered during $40 \%$ of admissions. Around $50 \%$ of patients received at least half their three day opiate dose on the day of admission. Not only were patients with alcohol-related AP more likely to receive opiate analgesia than those with gallstone disease, they also received a higher dose (median 42.8mg vs. $22.1 \mathrm{mg}$ over three days; $\mathrm{p}<0.001$ ). Pain level on admission was recorded for only $44.0 \%$ of presentations and this may explain the finding that pain level was not related to analgesia requirement, etiology of pancreatitis, lipase concentration and the development of severe pancreatitis. This is the first study to our knowledge to demonstrate that the lipase concentration on admission is of no use in determining the patient's opiate analgesic requirement.

Our data show no difference in the use of analgesics or dose given on day 1 and up to day 3 in patients with mild and non-mild AP. However, an Italian audit found patients with mild AP were more likely to receive NSAIDs and Tramadol than those with severe AP, where as the opposite was true for opioids (Pezzilli et al., 2007). It may be extrapolated that these differences in analgesia requirements arise after the third day of admission.

The high rate of opiate use reflects the potency of this class of analgesic and is not unexpected (Basurto et al., 2013). It is unclear why around 1 in 10 patients received no opiate over the first three days - possibly the pain had spontaneously resolved on presentation or it is a demonstration that clinicians sometimes provide inadequate analgesia. The underutilization of acetaminophen (paracetamol) and NSAIDs may reflect the scarcity of guidelines and poor acceptance of the concept of multi-modal analgesia. The low rate of use may be contributed to by patients being nil by mouth (possibly arbitrarily as in the traditional approach to managing patients with AP; perhaps due to vomiting or while awaiting imaging).

The evidence base on how best to relieve pain in those with acute pancreatitis is limited. Not only is there a scarcity of studies, but many are of low quality (Meng et al., 2013), and only five were suitable for a recent Cochrane review (Basurto et al., 2013). Not surprisingly therefore, only three of the nine recent guidelines mention analgesia (Takeda et al., 2006, Toouli et al., 2002, Pezzilli et al., 2008) - the first of which (from Japan) recommends NSAID use in mild AP. The Italian position statement recommends graded prescription of analgesia depending on the severity of pain (Pezzilli et al., 2008). The morphine-sparing ability of indomethacin in AP is long known (Ebbehøj et al., 1985). Acetaminophen (paracetamol) is recognized for its safety, effectiveness as an analgesic as well as its opioid-sparing effects (Remy et al., 2005). None of our patients were treated with buprenorphine, even though two randomized trials have demonstrated advantages to its use (Blamey et al., 1984, Jakobs et al., 2000). Pancreatic enzyme supplementation has been shown not to reduce pain scores in AP (Patankar et al., 1995). A recent review of hyoscine does not recommend the agent for patients with AP (Tytgat, 2007), and it is quite surprising this antispasmodic was administered to so many of our patients. However, hyoscine may have a role in managing biliary colic (Kumar et al., 2004). The fact that morphine constitutes the principal opiate in our series suggests resolution of the morphine and meperidine (pethidine) debate (at least in our hospital). Katerndahl traces the concept of morphine-induced sphincter of Oddi (SO) spasm to a 1965 textbook of Surgery by Bailey and Love (Spiegel, 2001). There is agreement that in patients without acute pancreatitis, at low dose, morphine increases wave frequency to a greater extent than pethidine but neither affects the SO basal pressure (Isenhower and Mueller, 1998, Thompson, 2001). At higher cumulative doses, morphine increases the basal pressure of the sphincter while pethidine does not (Isenhower and Mueller, 1998). While both are potent opioids, the metabolites of Meperidine (pethidine) accumulate in patients with renal impairment and may cause seizures. Meperidine (pethidine) also crosses the blood-brain barrier resulting in euphoria. 
Tramadol hydrochloride has been associated with seizures (Raiger et al., 2012). There is no evidence on the effects of these two opioids on SO in patients with AP.

The strengths of this study include the following: diagnosis confirmed by clinician rather than relying on administrative coding data which is prone to error (Zhan and Miller, 2003), large number of patients, relatively long time frame i.e. not just the first 24 hours. A major limitation of the study is the low frequency of documented pain levels on admission and the study's non-randomized design. In addition, the ME opiate dose may constitute an over simplification, as each of the medications has a different side effect profile. Timing of oral refeeding was not analyzed as those without a clear alcohol etiology were routinely fasted in preparation for abdominal ultrasonography. A small proportion of admissions with clinically acute pancreatitis due to alcohol may have underlying chronic pancreatitis, and this may have affected the analgesics prescribed. Future research may include a greater emphasis on multimodal analgesia, evaluation of the role of hyoscine or newer non-constipating analgesics such as slow release oxycodone with naltrexone (naloxone) (Davis et al., 2013).

The clinical implications of our study fall into two domains. As would be expected, opioids should remain the principal analgesic when patients with AP are initially assessed in the Emergency Department, but we found no evidence to support the ongoing use of hyoscine. Once the patient is admitted to the acute ward, clinicians could consider prescribing acetaminophen and Non-Steroidal AntiInflammatory medications, in addition to opioids, as part of a multimodal analgesia strategy.

Opioids are the main analgesic in patients with acute pancreatitis. Uniquely, this study demonstrates: 1) patients with alcohol-related AP require a higher dose of opioids than those with biliary AP; 2) lipase concentration on admission is of no use in determining the patient's opiate analgesic requirement, and 3) hyoscine is unhelpful in AP. We would suggest future guidelines on the management of patients with acute pancreatitis specifically mention analgesia, otherwise the analgesic pyramid tends to be forgotten and the wheel is re-invented each time a patient with acute pancreatitis is admitted.

\section{Abbreviations}

AP acute pancreatitis; ME morphine equivalent; NSAID Non-Steroidal AntiInflammatory; SO Sphincter of Oddi

\section{Acknowledgements}

Mr. James Hogan for providing statistical analysis. WiltshireHogan Limited. 91b Normandale Road, Normandale, Lower Hutt, New Zealand.

\section{References}

1. BANKS, P. A., BOLLEN, T. L., DERVENIS, C., GOOSZEN, H. G., JOHNSON, C. D., SARR, M. G., TSIOTOS, G. G. \& VEGE, S. S. 2013. Classification of acute pancreatitis--2012: revision of the Atlanta classification and definitions by international consensus. Gut, 62, 102-11.

2. BASURTO, O. X., RIGAU, C. D. \& URRUTIA, G. 2013. Opioids for acute pancreatitis pain. Cochrane Database Syst Rev, 7, CD009179.

3. BLAMEY, S. L., FINLAY, I. G., CARTER, D. C. \& IMRIE, C. W. 1984. Analgesia in acute pancreatitis: comparison of buprenorphine and pethidine. Br Med J (Clin Res Ed), 288, 1494-5.

4. BUTER, A., IMRIE, C. W., CARTER, C. R., EVANS, S. \& MCKAY, C. J. 2002. Dynamic nature of early organ dysfunction determines outcome in acute pancreatitis. British Journal of Surgery., 89, 298-302.

5. DAVIS, M., GOFORTH, H. W. \& GAMIER, P. 2013. Oxycodone combined with opioid receptor antagonists: efficacy 
and safety. Expert Opin Drug Saf, 12, 389402.

6. EBBEHØJ, N., FRIIS, J., SVENDSEN, L. B., BULOW, S. \& MADSEN, P. 1985. Indomethacin treatment of acute pancreatitis. A controlled double-blind trial. Scand J Gastroenterol, 20, 798-800.

7. ISENHOWER, H. L. \& MUELLER, B. A. 1998. Selection of narcotic analgesics for pain associated with pancreatitis. Am J Health Syst Pharm, 55, 480-6.

8. JAKOBS, R., ADAMEK, M. U., VON BUBNOFF, A. C. \& RIEMANN, J. F. 2000. Buprenorphine or procaine for pain relief in acute pancreatitis. A prospective randomized study. Scand J Gastroenterol, $35,1319-23$.

9. KOIZUMI, M., TAKADA, T., KAWARADA, Y., HIRATA, K., MAYUMI, T., YOSHIDA, M., SEKIMOTO, M., HIROTA, M., KIMURA, Y., TAKEDA, K., ISAJI, S., OTSUKI, M. \& MATSUNO, S. 2006. JPN Guidelines for the management of acute pancreatitis: diagnostic criteria for acute pancreatitis. J Hepatobiliary Pancreat Surg, 13, 25-32.

10. KUMAR, A., DEED, J. S., BHASIN, B. \& THOMAS, S. 2004. Comparison of the effect of diclofenac with hyoscine-Nbutylbromide in the symptomatic treatment of acute biliary colic. ANZ J Surg, 74, 573-6.

11. MENG, W., YUAN, J., ZHANG, C., BAI, Z., ZHOU, W., YAN, J. \& LI, X. 2013. Parenteral analgesics for pain relief in acute pancreatitis: a systematic review. Pancreatology, 13, 201-6.

12. PATANKAR, R. V., CHAND, R. \& JOHNSON, C. D. 1995. Pancreatic enzyme supplementation in acute pancreatitis. HPB Surg, 8, 159-62.

13. PEZZILLI, R., UOMO, G., GABBRIELLI, A., ZERBI, A., FRULLONI, L., DE RAI, P., CASTOLDI, L., CAVALLINI, G. \& DI CARLO, V. 2007. A prospective multicentre survey on the treatment of acute pancreatitis in Italy. Dig Liver Dis, 39, 838-46.
14. PEZZILLI, R., UOMO, G., ZERBI, A., GABBRIELLI, A., FRULLONI, L., DE RAI, P., DELLE FAVE, G. \& DI CARLO, V. 2008. Diagnosis and treatment of acute pancreatitis: the position statement of the Italian Association for the study of the pancreas. Dig Liver Dis, 40, 803-8.

15. RAIGER, L. K., NAITHANI, U., BHATIA, S. \& CHAUHAN, S. S. 2012. Seizures after intravenous tramadol given as premedication. Indian J Anaesth, 56, 55-7.

16. REMY, C., MARRET, E. \& BONNET, F. 2005. Effects of acetaminophen on morphine side-effects and consumption after major surgery: meta-analysis of randomized controlled trials. Br J Anaesth, 94, 505-13.

17. ROYAL AUSTRALASIAN COLLEGE OF GENERAL PRACTICIONERS. 2012. Pain Management [Online]. Royal Australasian College of General Practicioners. Available: http://www.racgp.org.au/yourpractice/guidelines/silverbook/commonclinical-conditions/pain-management/ [Accessed 27/05/2013 2013].

18. SPIEGEL, B. 2001. Meperidine or morphine in acute pancreatitis? Am Fam Physician, 64, 219-20.

19. TAKEDA, K., TAKADA, T., KAWARADA, Y., HIRATA, K., MAYUMI, T., YOSHIDA, M., SEKIMOTO, M., HIROTA, M., KIMURA, Y., ISAJI, S., KOIZUMI, M., OTSUKI, M. \& MATSUNO, S. 2006. JPN Guidelines for the management of acute pancreatitis: medical management of acute pancreatitis. J Hepatobiliary Pancreat Surg, 13, 42-7.

20. THOMPSON, D. R. 2001. Narcotic analgesic effects on the sphincter of Oddi: a review of the data and therapeutic implications in treating pancreatitis. Am J Gastroenterol, 96, 1266-72.

21. TOOULI, J., BROOKE-SMITH, M., BASSI, C., CARR-LOCKE, D., TELFORD, J., FREENY, P., IMRIE, C. \& TANDON, R. 2002. Guidelines for the management of acute pancreatitis. J Gastroenterol Hepatol, 17 Suppl, S15-39. 
22. TYTGAT, G. N. 2007. Hyoscine butylbromide: a review of its use in the

treatment of abdominal cramping and pain. Drugs, 67, 1343-57.
23. WYSOCKI, A. P. \& CARTER, C. R. 2007. Acute pancreatitis. Surgery, 25, 4956.

24. ZHAN, C. \& MILLER, M. R. 2003. Administrative data based patient safety research: a critical review. Qual Saf Health Care, 12 Suppl 2, ii58-63. 